\title{
Vidas Maiúsculas ou A Invenção da Vida Clara Haquira Osakabe (UNICAMP)
}

\section{RESUMO}

Há no Horto de Incêndio um poema visceralmente atual, "Sida", em que o autor, Al Berto inventa uma corajosa expressão para o quase improferível desse Mal moderno. O resultado dessa invenção é uma surpreendente superação dos padrões de representação da doença física e da morte, enfim das afecções mais pungentes que a humanidade enfrenta na contemporaneidade. Como isso se dá e o que estaria na raiz desse processo? Tentarei aventar alguma hipótese convincente para responder a essas questões. Palavras-chave: Al Berto, SIDA, poesia portuguesa contemporânea.

Em 1992 perdíamos em São Paulo, além do grande amigo, uma das maiores referências intelectuais e humanas dos nossos tempos de Universidade. Presença querida sempre, ele contaminou-nos, desde os primeiros contatos, com o vírus do inconformismo, da briga por uma percepção sempre heterodoxa de tudo aquilo que poderíamos denominar "realidade". Daí que tenha permanecido entre nós a lembrança de suas várias e expressivas manifestações:de nojo, de desconfiança., de indignação, de espanto, de alegria e do imenso prazer da vida. De tudo isso, materialmente, sobrou muito pouco, eu diria. Não deixou uma obra vasta. Seus ensaios irrepreensíveis em epistemologia da linguagem com a indefectível capacidade de organizar o sensível ficaram publicados uns, inéditos outros, confinados aos limites de um esfera especializada de saber, tão à revelia dele cujo maior horror era exatamente o da especialização. No entanto, sua obra maior permaneceu. A Vida Clara, ensaio sobre Píer Paolo Pasolini constitui não só referência decisiva na compreensão do grande intelectual italiano, mas sobretudo o legado luminoso da visão com que nosso querido entendeu o conturbado fim de século cujos últimos anos ainda chegou a vislumbrar ${ }^{1}$. Falo de Michel Lahud, filósofo cujo trajeto biográfico e intelectual cruza com os interesses mais agudos que vivenciamos a partir da década de 60. Tendo vivido dois conturbados anos ( $68 \mathrm{e}$ 69) na Faculdade de Filosofia da USP e tendo vivido a grande crise política que culminou com a cassação dos direitos civis de boa parte dos grandes mestres da lendária rua Maria Antônia, ainda desorientado intelectualmente, partiu para Paris, agora com o objetivo de estudar com Michel Foucault, a grande referência de sua geração ${ }^{2}$. Mas a atenção que lhe chamavam naquele momento as questões suscitadas pelo debate estruturalista levaram-no a uma espécie de retiro. Partiu para Aix-en-Provence num estratégico repouso positivista ${ }^{3}$, mas que no fundo iria sedimentar-lhe toda a reflexão posterior a respeito daquele filósofo e do saber intelectual e sua inserção no contexto 
mais contemporâneo. Não por acaso, a descoberta de Pasolini se faria aí nesse momento criando para sempre uma cisão entre toda a demanda de um aprofundamento sistemático no plano da filosofia da linguagem e a reflexão convulsiva profundamente inconformada do cineasta com os rumos da cultura italiana no contexto do pós-guerra e das chamadas conquistas libertárias depois dos anos 50. A trágica morte do grande cineasta em 1975 dificilmente se poderia explicar fora desse contexto que conjugaria formas opressivas oriundas de carências diversas e sobretudo de deslocamentos morais em que se confundem afetos e afecções.

Comizi d'Amore, ${ }^{4}$ típico exemplo de cinema verdade empreendido por Pasolini no início dos anos sessenta, é o ponto de partida para a reflexão de Michel. Naquele filme, o cineasta pretendia investigar, através de enquetes e comentários, como se entendia amor e sexualidade na Itália do período.O núcleo histórico flagrado pela enquete teve a ver diretamente com a assimilação da Itália por um neocapitalismo em que noções como bem estar material e consumo têm poder decisivo. A questão da sexualidade prenunciada pelo filme-enquête está intrínsecamente ligada a um forte mecanismo de tolerância, por definição, decorrente da ideologia do bem estar. Formulada nestes termos, a percepção pasoliniana estaria bastante próxima da de um Foucault como anos depois de poderia observar num artigo revelador deste último, mas se distinguiria dele pelo fato de que essa tolerância resultava de uma falsa resolução de uma má cultura do sexo, persistente no caráter compulsivo das novas tendências sexuais, modernas ou tecnificadas ( hedonismo liberal, permissividade sexual, signos de uma retumbante modernidade italiana ).Essa formulação, considerada em nossos dias, nas sociedades contemporâneas, são mais do que esclarecedoras já que se aguçaram os mecanismos a que Pasolini classificaria como fascismo de consumo, propagação e compulsão sexual.

Como alertaria o próprio cineasta, a emergência dessa nova onda, dita civilizatória, iria apagando vagarosamente os sinais da natureza na vida cotidiana dos italianos, tornando a "idade dos pirilampos" um obsoleto resquício nostálgico. A incorporação desses valores por parte da juventude subproletária representaria o processo mais devastador de dissolução da natureza na vida italiana da época. E essa perspectiva marcava o ponto nuclear e decisivo do Pasolini posterior e também do próprio Michel que definitivamente deslocou seu interesse do campo da linguagem verbal para o campo do cinema, tal como o concebia Pasolini. Ou, se se quiser,do campo da representação para o campo do real, entendendo-se o cinema como a semiologia desse real. A insistente atração de Pasolini pelos cenários de periferia, a incorporação no seu elemento de figuras nascidas das classes populares, constitui a marca forte de um cinema que ao contrário de uma visão neo-realista, consagra a vitalidade e o frescor ainda virginal de setores ainda não contaminados pelo consumismo que reduziria afeto, sonhos e sexo em moeda de troca. Num belo artigo intitulado "Pasolini e o Brasil", escrito por ocasião dos dez anos da morte do autor," Michel iria trazer para o leitor brasileiro um surpreendente, mas coerente Pasolini, em que a apologia de um Brasil, suspenso nas contradições entre fascismo e liberdade, se fazia exatamente na experiência, vivida num Rio suburbano, num Rio de favela e marginalidade, mas em que, apesar de sua contrapartida violenta, florescia a inocência dos afetos e onde o sexo tinha ainda a ver com a ternura da aproximação dos corpos.

Mas, o que ainda não estava claro para um Michel de 1985, como não estivera para Pasolini em 75, é que o processo de decomposição moral e de destituição da posse dos corpos e dos afetos encontrava, já nos finais da década de 70, o seu componente mais letal. A violência de que fora vítima Pasolini nessa espécie de imolação do próprio corpo, tornado moeda e matéria, assumiria a seguir as proporções do estigma. Tida inicialmente como o "câncer" gay, imediatamente a Aids propiciou a emergência de um discurso moralista e discriminatório que repunha em termos dramáticos a velha relação 
entre sexo e pecado, ou mais precisamente, entre homossexualidade e maldição. O Mal instalava-se na sociedade do bem-estar e o consumo do corpo iluía-se num estado de insolvência e morbidez. ${ }^{6}$

Michel Lahud morreu de Aids, e ele mesmo afirmava não saber de quando remontava a conversão do seu corpo à doença fatal. Como era de se esperar, em nenhum momento deixou que os estigmas o derrotassem e, sobretudo, em nenhum momento abriu mão da herança pasoliniana. $\mathrm{O}$ sinais vivos da doença menos que sinais de uma deterioração moral ou física guardaram sempre e paradoxalmente a força de uma indestrutível crença em que os pirilampos pasolinianos ${ }^{7}$ ainda povoassem um vale qualquer.

Para mim fica impossível ler o poema "SIDA" de Al Berto sem remeter-me à figura de nosso amigo. Não tanto pela referência explícita à doença, mas sobretudo pela precisão de sua construção.Mais ainda, todo o contexto imediato do livro em que se acha contido, Horto de Incêndio ( Lisboa. Assírio e Alvim.1996), testemunha a luta surda e vitoriosa com que a realidade se impõe contra os males da época e contra o grande Mal que é a moral violentamente tolerante de nossa sociedade. A grande tradição de nossa poesia, pelo menos a partir de fins da Idade Média, teve diante dos males físicos e da morte um relação de temor e nojo. Concordemos com as idéias de Jean Delumeau que situa entre os séculos XIII e XIV ( Le peché et la peur. Paris.Payot.....) o momento inaugural de uma estética do macabro, nascida sobretudo para instaurar no homem o terror em relação à transitoriedade da matéria em geral e do corpo em particular.

Espetáculos, como a dança da morte ou os ofícios fúnebres de corpo presente, ao mesmo tempo, em que tornavam contundente para o fiel a eloqüência da morte, tinham por fim persuadi-lo da terrível associação entre corpo, pecado e punição. Jean Delumeau fala de uma espécie de pedagogia do terror cujo fim não seria tanto o da elevação do espírito mas o da instauração da contrição pela negação da matéria. Com nuances distintas, essa estética fez tradição e chegou mesmo a constituir-se num dos componentes mais evidentes do Ultra Romantismo. E com função distinta, foi também uma das bases do naturalismo.Em todos os momentos, há resquícios do culto do horror, com uma resultante inevitável: o rebaixamento dos sentimentos mais sublimes ou a aniquilação dos padrões existenciais como os afetos ou os prazeres. Superado o componente religioso, ficava assim sob as manifestações macabras um inevitável componente moral a minar no leitor quaisquer resquícios de hedonismo. No Brasil como em Portugal a tradição não foi diferente, embora não tenhamos tido, exceção feita a Gomes Leal e Augusto dos Anjos, poesia macabra na grandeza de um Baudelaire.

Essa tradição, diríamos calcada numa visão mais naturalista do corpo em deterioração, em alguns momentos, vem associada a uma outra, essa mais ligada aos rituais de homenagem aos mortos. Chamaríamos a ela de estética do fúnebre. Embora tenha feito ela parte dos rituais do memento moris, a tentação do macabro neles se atenuava cedendo lugar a uma louvação contrita do morto.As pesadas cerimônias que ainda persistem em rituais religiosos como as que foram mostradas durante as exéquias de João Paulo II, a solenidade dos cantos, o predomínio da cor púrpura, o odor os incensos mais revelam o fascínio pela morte do que sua recusa. Talvez mais do que na poesia macabra, fale aí a força sinestésica da base simbólica: o roxo do sangue macerado, o incenso, o odor forte da cera ou matéria em dissipação, queimando-se, a fusão entre a tristeza do roxo e o fulgor de franjas douradas. De qualquer forma, o passamento do corpo, seu sofrimento e sua deterioração, se deixam encobrir pela força dos elementos simbólicos em que, como acabei de dizer, fala mais de perto a atração do que a repulsa, decorrente do poder de sedução do próprio luto. Uma da páginas mais memoráveis que nossa literatura produziu nessa linhagem, vem a ser a famosa "Marcha Fúnebre ao Rei Luís Segundo da Baviera" que se acha publicada nas diferentes versões 
do Livro do Desassossego de Fernando Pessoa ${ }^{8}$, em que o poeta realiza a mais drástica contraposição entre pompa e esvaziamento, entre a magnitude do Reino sem Fim da Morte e a Infinitude de seu vazio.

A intersecção entre esses dois sistemas de expressão, o macabro e o fúnebre, comporia uma espécie de território comum das representações elegíacas na nossa tradição e assinalaria pela força desta mesma tradição uma quase impossibilidade de pensar-se o luto e sua tristeza para além de seus limites.

É nesse sentido que o poema de $\mathrm{Al}$ Berto constitui uma convocação à reflexão sobre os processos de representação das perdas em nossos dias e sobre o significado da superação de tais processos. Em segundo lugar, seria também a convocação a uma rediscussão de questões que a percepção de Pasolini sobre sexo e afeto, via Michel, acabou por formular para as décadas mais avançadas do século findo, fundindo num mesmo território política, poesia, afetos e afecções.

Retomo aqui as reflexões de Michel sobre Pasolini no Brasil da década de 70 quando incógnito teria ele passado pelo Rio e teria, segundo seu poema, vivido um Rio avesso à paisagem turística e onde se fazia presente a imagem de uma marginalidade acuada pela pobreza e pela dureza do fascismo do regime militar. Apesar disso, como ocorreria com as locações de seus filmes, o cineasta registraria na estética declaradamente pobre de suas imagens, uma espécie de fulgor resistente nascido da pureza de um mundo intocado pelo materialismo consumista, pelo sexo tornado moeda. Um universo ainda avesso ao mal e disponível aos afetos e nesse sentido inteiramente imune às afecções físicas e morais.

Pois o que nos revela o poema de $\mathrm{Al}$ Berto é uma extraordinária formulação de um estado de coisas de um mundo ainda não totalmente submerso na sua própria inviabilidade. Um mundo já sem pirilampos? É o que passaremos a examinar.

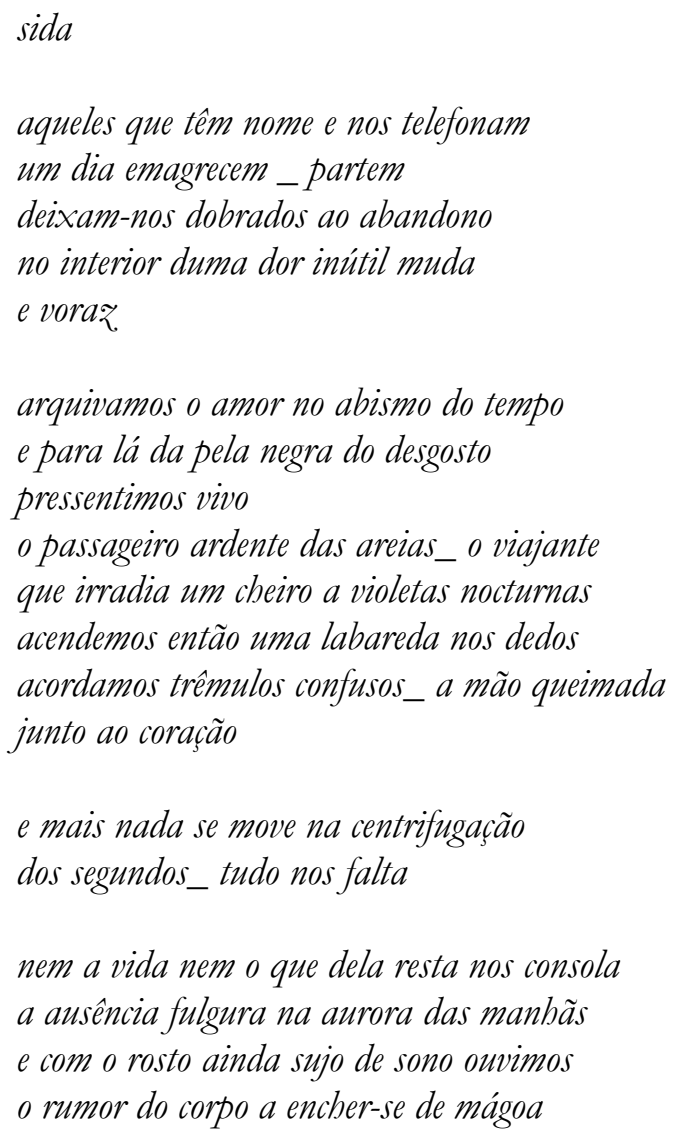


assim guardamos as nuvens breves os gestos

os invernos o repouso a sonolência

o vento

arrastando para longe as imagens difusas

daqueles que amamos e não voltaram

a telefonar.

(Horto de Incêndio. In O Medo, pp 621)

Em primeiro lugar, consideremos que o poema enfrenta desde o título a impossibilidade da poesia elevada. A Aids não ganhou até hoje nenhum traço de positividade, e nem consta do registro de suas origens nenhum componente dignificante, pois , desde o início, pareceu ligada a aspectos mais negativamente marcados da vida cotidiana: sexo, promiscuidade e devassidão.Que componente irrevelado poderia transformá-la em matéria poética e oferecer-se aos sentidos que redimem a dor e a deterioração?

Antes de mais nada, Horto de Incêndio,( 1996), comporta desde o título a ambivalência dos seus símbolos: a imagem ígnea, quase obsessiva ao longo da poesia do autor, aparece no poema que dá título ao Livro com o significado mítico que superpõe vida, destruição, imolação, sacrifício e ressurreição, paixão, tudo de uma só vez. Saliente-se: uma imagem que não comporta nenhum significado de sossego e placidez

borto

bomens cegos procuram a visão do amor onde os dias ergueram esta parede intransponivel

caminhos vergados no zumbido dos ventos

com os braços erguidos _ cantam

a linha do horizonte é uma lâmina

corta os cabelos dos meteoros_corta

as faces dos homens que espreitam para o palco

nocturno das invisiveis cidades

escorre uma linfa prateada para o coração dos cegos

e o sono atormenta-os com os seus sonhos vazios

adormecem sempre

antes que a cinza dos olhos arda

e se disperse

no fundo do muito longe ouve-se

um lamento escuro

quando a alba se levanta de novo no borto

dos incêndios

prosseguem caminho

com a voz atada por uma corda de lírios

os cegos 
são o corpo de um fogo lento_ uma sarça

que se acende subitamente por dentro.

(Idem. p. 608.)

Quem habita o horto-mundo são os homens cegos que procuram a visão do amor que se lhes proíbe nesse lugar de inviabilidades onde vivem seu eterno sacrifício.Qualquer alusão à carência afetiva humana não será casual.Mas essa carência longe de um poder disfórico, neutralizador, tem o impacto do desejo, aquele que converte o corpo em sarça ardente ou que converte a opacidade da ausência e da cegueira na incandescência febril daquilo que por força da fricção com o sagrado incendeia-a, aniquila pela pujança maiúscula da negação da tibieza e do conforto. Horto de Incêndio evoca assim a contraposição entre a solidão e reclusão impostas pela sombra e a ignição que o poder transfigurador do amor impõe à cegueira e à obscuridão. A sarça ardente bíblica, o elemento sensível pelo qual se faz a experiência metafísica de Deus é a representação mais surpreendente do corpo em chamas que se, de um lado, superam a cegueira, confirmam-na no seu poder de redenção aniquiladora. Uma percepção solenemente sacrificial impondo-se como lei iniludível acima da obscuridão e da própria cegueira.

O poema que vem a seguir ( "ACORDAR TARDE”) tangenciará como um ensaio tateante a questão do poema "Sida". Busca as origens do Mal, inutilmente: "Passas a lingua na cola dos selos lambidos por assassinos- e a tua mão segurando a faca cujo gume possui a fatalidade do sangue contaminado dos amantes ocasionais". Verdade única e irrefutável: a contaminação, o poder assassino do contágio, vindo da saliva ou do sangue, mas que imprimiram o poder da destruição no trânsito suposto pelos selos lambidos ou no afeto que, apesar de fortuitos, sedimenta mesmo os amores ocasionais. O certo é que alguma coisa se estancou na troca dos líquidos que resultou na fatalidade. E o rio parou de correr, o serviço postal não funcionou no dia seguinte, porém a noite redimiu na repentina luminosidade o estancamento (a morte). O sujeito porém estará ainda sozinho a meio caminho entre seu obscurecimento e a fulguração da luz anunciada na noite ou no mortal brilho do meio dia que apesar daquilo que se estancou parece afirmar-se como uma fatalidade. Ou seja, a sarça que pode incendiar-se por dentro subitamente.

O território está assim pronto para que $\mathrm{Al}$ Berto encare de frente como a sarça que arde, ela , a fatal força que entre o afeto e o assassinato ilumina o amigo próximo, o objeto do afeto transformador. (Cabe notar antes disso que as imagens sobre as quais se organizam esses dois poemas são reiteração de uma espécie de sistema de representação que desde pelo menos $O$ último habitante (1983) comparece constantemente na obra desse poeta. Retomemos agora o poema central de nosso ensaio.

Além do título, o primeiro impacto causado pelo poema está logo no seu início: "aqueles que têm nome e nos telefonam um dia emagrecem"- Ao forte apelo provocado pelo título curto e explícito, o poema se inicia com a denúncia de uma negação:quem adoece de sida? O verso inicial parece querer dizer que o paciente ou alvo do adoecimento, aquém das estatísticas que esfriam os sentimentos de aflição e perda, por conta do inevitável anonimato, qualifica-se como um dos nossos que, dentre outros atos, procuramnos, mesmo que por telefone. Isto é, os que adoecem têm relevo individual suficiente para fazer chegar até nós confidências, alegrias e espantos, confirmando com isso sua qualificação afetuosa, sua pertença ao círculo sempre restrito dos que efetivamente amamos. Assim, como se censurasse em nós mesmos, a elisão da dor e da perda, o poema censurasse o fato de que a doença só se nomeia na instância do anonimato, como uma vergonha ou uma mácula de que todos fugiríamos aterrorizados. Cabe aqui exatamente notar que esse primeiro grande impacto do poema resulta de um conflito 
entre um discurso oficial e aquele dos afetos, justamente o que brota da intimidade, mesmo que temerosa. A afirmação desse último discurso é que justifica a nudez do abandono a que nos deixa reduzida a partida daqueles que mais nos procuram porque partiram. E'um abandono que só cresce e se intensifica por conta de que por essa partida em que se separam os que ficam e os que se foram, definem-se dois universos distintos: o da mágoa e o da redenção. O da mágoa que se explicita na seqüência:

E mais nada se move na centrifugação dos segundos_tudo nos falta/nem a vida nem o que dela resta nos consola..." e o da redenção que ocupa os finais da estrofe 2 e a estrofe 3:"pressentimos vivo/o passageiro ardente das areias_o viajante/que irradia um cheiro a violetas nocturnas" Entendamos a redenção para que fique mais assente a força afetiva com que o poema termina.

A imagem daquele que partiu, recompondo-se da pele negra do desgosto, ali está vivo, ardente sobre as areias, irradiando um cheiro a violetas noturnas. Essa imagem visionária das areias, constitui uma das paisagens reiteradas de $\mathrm{Al}$ Berto, do mesmo modo como se concentram nela imagens recorrentes que compõem a base de sua poesia: o viajante, o percurso noturno, a fusão entre perfume, amor, morte e medo que neste caso exalam as violetas noturnas. O que me parece mais notável é que a imagem daquele que partiu tem aqui uma outra inserção. Solitária, é bem verdade, fugaz como qualquer objeto desejado, mas fulgurante, vivo e ardente. Redimido do Mal que anunciaria o desaparecimento do seu corpo, eis que ele lá está para além da "pele negra do desgosto". Do lado de cá, no plano da mágoa está, no entanto, o poeta e aí o texto evoca mais uma imagem cara a Al Berto: os dedos em chamas. Tomo a liberdade para apoiar minha interpretação num outro poema denominado "Prefácio para um livro de poemas", texto que aparece nos Poeira de Lume, datado de 1997, incluído no Volume O Medo de edição posterior( v. pp649/650 da edição de 2005). Trata-se de uma notável peça de reflexão sobre a própria poesia e em que o fazer poético que se confunde inteiramente com a criação do mundo e das coisas e que se dá por força do impulso da mão e dos dedos. Falando de um eu/outro, expulso além das muralhas da cidade, diz o sujeito: ..."víamos o tremelicar da lu₹ nas veias e o lodo das emoçôes na ponta dos dedos." e lemos ainda : Depois o homem abre a mão, uma laranja surge, esvoaça. I As cidades (como em todos os livros que li) ardem. Incêndios que destroem o último coração do sonho./ Mas aquele que se veste com a pele porosa da sua própria escrita olha, absorto, a laranja." Há, assim, na escrita o gesto físico impulsionado pelas mãos e pelos dedos, gesto que ao grafar os versos tem a incandescência da verdade. " As cidades (como em todos os livros que li) ardem. Incêndios que destroem o último coração dos sonhos." Retornemos ao poema onde estávamos ( do lado de cá), do lado das mágoas em que o sujeito assinala "acendemos então uma labareda nos dedos/ acordamos trémulos confusos_" A composição da poesia seria um processo de combustão com que o sujeito responde à visão luminosa daquele que partiu, mas resulta com a aurora das manhãs num sentimento de ausência fulgurante, o corpo rumorejando de mágoas, o sentimento do abandono resultante do silêncio do telefone e da falta marcada pela intransferibilidade de sua voz e de seu nome. Mas se a imagem que resulta é difusa, o retrato constituído pelo ardor da poesia não o é. Aquele que partiu tem a consistência onírica e luminosa do desejo, negando de vez quaisquer traços que o anonimato dos boletins médicos, ou o estigma dos discursos morais, possa ter impresso sobre a fatalidade. De tudo resta a mágoa da perda, a ausência do objeto amoroso. Mas resta soberana ainda a afirmação vigorosa do afeto que confere ao corpo a incandescência metafísica da sarça bíblica.

Estamos aí às vésperas da contemplação máxima do inomeável que só parece depender do gesto daqueles que amamos e que partiram, autorizando-nos a desenhar com nossas mãos e dedos.

Escondido nas contradições de um Portugal fim de século, Al Berto no poema 
SIDA permite levar adiante as idéias que Michel teria acentuado em Pasolini.

Desafinado com a modernização da Itália dos anos 60/70, a Pasolini repugnava com a implantação do fascismo de consumo, a instrumentalização do sexo e a ruptura de sua prática para longe dos afetos. Recordemos aquele poema sobre o Brasil e os comentários de Michel.Um dos núcleos do texto está naquele momento em que o sujeito chega conduzido pelo "guia", pequeno prostituto da cidade, à Favela, em que descobre a invariabilidade da vida, descoberta que, nos seus termos de poeta, requer inteligência e amor. Ou, mais precisamente, o amor que subjaz a própria perdição que ele, subversivo das cidades, sem o saber procurava. Convém reler com atenção a passagem "Não sabiamos que pouco a pouco nos revelaríamos, prudentemente,/ uma palavra após a outra,/ dita quase distraidamente:/ sou comunista e: sou subversivo;/ sou soldado numa divisão especialmente treinadal para lutar contra os subversivos e torturá-los; mas eles não sabem; / ninguém se dá conta de nada; só pensam em viver/ (me falando do subproletariado) / A Favela, fatalmente nos esperaval eu, grande conhecedor, ele, guia-/ seus pais nos acolheram, e o irmãozinho nu/ recém saído de trás do oleado _ I pois é, a invariabilidade da vida, a mãe converson comigo como Maria Limardi, me preparando a limonada/sagrada do bóspede: a mãe de cabelos brancos, mas ainda jovem de carne;/ envelhecida como envelhecem os pobres, embora moca;/ sua gentileza e a de seu companheiro,/fraternal com o filho que por sua exclusiva vontade era agora como um mensageiro da Cidade_/ Ah, subversivos, procuro o amor encontro vocês./ Procuro a perdição e encontro a sede de justiça. " Hierarquia"( trad. de Michel Lahud in A Vida Clara (anexo), p 127.

Pela percepção particular de seu olhar de artista, Pasolini se depara na miséria do morro, por detrás da perdição que o arrastara até ali, com a sua Cafarnaum, com a via da revelação do mistério: o intenso território dos afetos que vai além dos esgotos a céu aberto. Diríamos que em pleno sinistro Brasil de 1970 num mundo em que não se veria nada além da caça aos comunistas, da miséria, e da prostituição, Pasolini tem mais uma vez confirmada a realidade que só a poesia pode revelar-lhe. De costas para um Rio de Janeiro anódino, identifica-se ele como o habitante do espaço qualificado de Cidade, Metrópolis mítica, resultado da própria mercantilização moderna. Alguém the dá a mão e o guia para aquele outro espaço, à Favela, não sub-produto da Metrópolis, mas o resíduo mais intacto do que a Cidade não conseguiu incorporar e de onde pode nascer a grandeza avassaladora dos afetos. Pasolini confirmará que é junto das classes abandonadas, dos jovens envelhecidos e crianças nuas que um Cristo sem metafísica irá encontrar-se entre pares, a mesa posta para alimentar uma outra dimensão da fome.

Sobre isso é que Michel afirmará: "As impressões e juízos de Pasolini sobre o Brasil não emanam, de fato, nem das convençôes dominantes, nem das fileiras regulares dos inimigos do poder; mas daquelas experiências bárbaras-portanto singulares e absolutamente não codificadas- de quem 'vive dentro das coisas e inventa como pode o modo de nomeá-las' ( A Vida Clara,idem . p 123). Assim, a vivência de Pasolini no Rio ou em qualquer lugar do mundo pautar-se -ia numa divisa ' Lutar com as armas da poesia', comportando-se com isso, sempre desfocado da convenção, sempre alheio à consistência consentida dos discursos. Afirmaria Michel: "Lutar com as armas da poesia: é a divisa pasoliniana, então que define toda uma forma de engajamento real e não enfadonhamente retórico e moralista, fixando-lhe os únicos propósitos e compromissos pertinentes. Por um lado, o combate obstinado ao entorpecimento, a essa tendência bumana de acomodação, na própria normalidade que atrofia nossa consciência crítica tanto da realidade que nos cerca como de nós mesmos." ( A Vida Clara,Idem. p.123). Nenhuma morte seria mais coerente que aquela que teve Pasolini, imolado pelo amor que buscou sob a perdição, transformando o ato de partir num incandescente libelo contra a tolerância sexual do viés consumista. Assassinado por este mesmo viés, sua morte evoca não tanto o ritual da imolação do cordeiro, mas sim aquela pira incandescente com que o desejo consagra a sarça mais anônima e ressequida.

Anos mais tarde, consumido pelo mesmo fogo da incessante busca do que sob os 
corpos anônimos se ocultava, seu discípulo, seu intérprete mais rigoroso, de nome inteiro Michel Lahud, como tantos outros, emagrecia, não nos telefonava mais e partia.

Deixa o livro $A$ Vida Clara ainda inédito, como uma recomendação de vida a todos nós. Nos termos de $\mathrm{Al}$ Berto em seus últimos poemas, ele era o próprio homem que possuía uma cabeça de vidro e que habitava fora das muralhas da cidade, de onde ele mesmo sempre se retirou. Sobre sua morada, o próprio Al Berto teria já a teria indicado quando ao amigo distante teria nomeado "o passageiro ardente das areias- 0 viajante/ que irradia um cheiro a violetas noturnas."

$\mathrm{O}$ mundo de $\mathrm{Al}$ Berto sempre povoado de ausências denuncia pelo seu contrário a situação dramática do nosso homem finissecular a quem se interdita a vivência pura da vida e o fruir mais inocente das relações de prazer.Num momento de duro realismo , diria ele: "Mas, no cansaço do torna-viagem o desalento de tudo/ o mapa ficon aberto no sitio onde desapareceste/ ouco o atlântico vivando de abandono/ enquanto os dedos se cansam a pouco e pouco/ na lenta escrita de um diário_ depois/ fecho o mapa e vou/ pelo crueldade desta década sem paixão/. (Horto de Incêndio. In $O$ medo. P. 631)

É um realismo ao qual parece rebater com a supra-realidade que vinga a perda e o desaparecimento, quando diz:

Corre/ corre um vento pelas fissuras da pele_vento/ de pó enferrijado abrindo feridas nos animais vivos/ colados à memória onde/ uma serpente mergulhou no sangue e/ desata a fulgurar/ sopra um vento pelo peito do mareante/ desperta a florescência pálida do plancton_varrel a noite e lava as mãos dos condenados à mortel entre um vento/ vento de febre sismo de orquideas que acalma/ quando acendes a luze abres as asas/ vibras e/ levantas vô. Horto do Incêndio.55/56

Retomo aqui a metáfora dos pirilampos e o seu significado em Pasolini, lembrando que perpassa por toda a biografia do cineasta esse olhar que tenta perscrutar por detrás das coisas mais insólitas uma espécie de resíduo adâmico: o dialeto friulano, os jovens infelizes, a favela, as periferias do mundo. Michel falaria aí na capacidade que Pasolini teria de conferir à nostalgia um caráter de resistência ao declínio humano. E, como afirmei acima, confere ao olhar da poesia o poder de reconquistar aquele resíduo e alterar a ordem canônica das coisas. O poema "Sida" resultaria desse olhar e o complementaria com o gesto que consagra pelo fogo o significado mais intocado e remoto dos afetos. É a manifestação que fere a ordem definida e constituída da nossa contemporaneidade.

E quando se fala em ordem contemporânea, fica inevitável incidir no lugar comum da pós-modernidade ${ }^{10}$, noção que resulta do esforço de compreensão dos fundamentos mais cruciais do mundo pós-cinqüenta, dentre esses, o "desaparecimento" dos Universais, a relativização dos valores e com isso a objetualização da relações e procedimentos, outrora ditos, humanos. Nesse sentido, pós-modernos já seriam os padrões percebidos por Pasolini no comportamento dos jovens que entrevistou em Comizi D'amore, comportamento a que o cineasta incluiria na já referida noção de fascismo de consumo, forma de autoritarismo que convertendo o afeto em matéria, leva a conversão do sujeito em objeto e com isso, a transformação do mundo na mediação de si próprio. Nesse sentido é que se pode perceber no Pasolini, visto por Michel, um libelo que clama pelo direito ao exercício de uma liberdade que para ele só se realiza nos resquícios de um mundo sem mediações. Outros autores como Giani Vattimo, pensarão diferentemente essa questão, mas sintomaticamente não se renderão ao panorama fatalista de arautos dessa nova era, avessa à novidade e à história. Um paralelo, ou talvez uma contraposição curiosa entre ambos os autores nos leva a captar em seu pensamento, mais do que uma constatação, um desejo. Vattimo localizará a saída ( ou escoadouro ? ) das inviabilidades pós-modernas na surpreendente afirmação de uma espécie de recomposição da ordem religiosa que resultaria do próprio momento de decomposição do monoteísmo cristão ou da dominante metafísica na filosofia, trazendo 
à cena a pluralidade cultural-religiosa ou, nos termos de Nietzche, inventando novos deuses. O que fica por baixo dessa formulação é seguramente a antevisão de um respiradouro nessa espécie de câmara de asfixia em que se transformou o mundo contemporâneo, recurso através do qual ganha fôlego o discurso que reinscreve no horizonte do homem a possibilidade da liberdade moral de transitar num espaço já livre da homogeneidade dos modelos de consumo. A visão de Pasolini é um pouco mais drasticamente materialista, mais trágica já que pressupõe necessariamente o confronto radical entre a homogeneidade e sua recusa ou destruição: antevisão de um mundo que nasce não só da margem, mas dos escombros da sociedade contemporânea. Aproxima os dois pensadores o fato de ambos contarem com uma inevitável e natural pluralização de modelos e resultados decorrentes da completude dos mecanismos reprodutivos e auto-aperfeiçoadores da pós modernidade. Em outros termos, ambos parecem apostar em resultados semelhantes. Vattimo na natural conseqüência heterogenizadora da dissolução do modelo filosófico e religioso do século XIX e Pasolini na incapacidade totalizante dos mecanismos gerais do consumo. Recomposição do sagrado para o primeiro, sobrevivência dele para o segundo, em ambos os casos, uma redefinição da heterogeneidade como condição da liberdade. Pasolini consagrará à poesia o poder dessa redefinição. ${ }^{11}$

Retorno aqui primeiramente a $\mathrm{Al}$ Berto de quem recordo este versos, já citados acima: Mas, no cansaço do torna-viagem o desalento de tudo/ o mapa da europa ficou aberto no sítio/ onde desapareceste/ ouço o atlântico uivando de abandono/ enquanto os dedos se cansam a pouco e pouco/ na lenta escrita de um diário _ depois/ fecho o mapa e vou / pela crueldade desta década sem paixão/ (Horto de Incêndio.in O Medo.p 631-negritos meus)

O poema escrito já nos últimos anos de vida do autor refere-se sintomaticamente à década final do século. Peço a atenção para que se note que a qualificação "sem paixão" refere-se à década e não necessariamente ao sujeito. O poema inteiro, ao contrário da vitalidade ainda que mortífera de outros que o antecederam, desmobiliza-se num pesado clima de desânimo e ausência. Desalento, desaparecimento, abandono, cansaço são termos incisivos que reiteram aquela mesma idéia de um mundo sem horizonte. Nem mesmo os dedos a quem em outros textos, o poeta atribui a função incendiária pelo gesto da escrita, nem mesmo eles resistem ao cansaço, o despojamento da vontade. Tudo isso leva-me a perguntar se não se chegou aqui àquele estado de neutralidade, àquela exaustão dos sentidos e da vontade que presidiria a indiferença dessa década. Sem paixão, como diz o poeta. Sem sabor, diríamos nós. E aqui retomemos outro fragmento, em parte já citado anteriormente:

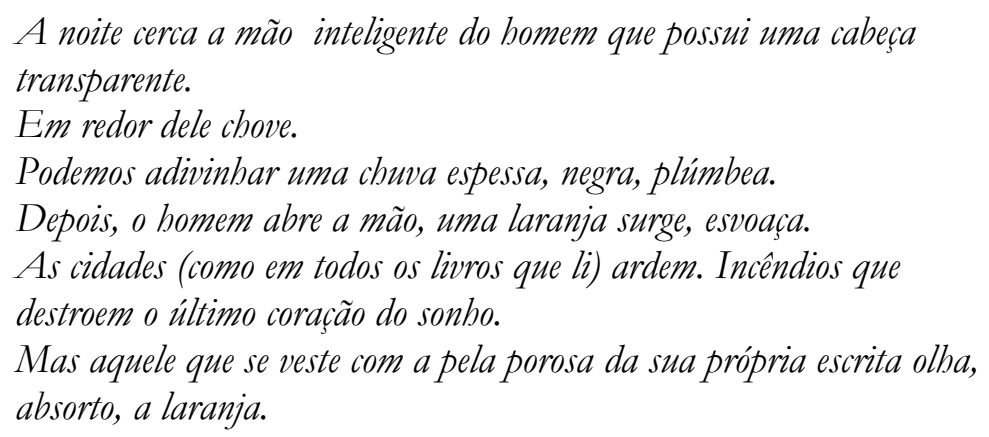

Onde mora o bomem que ousou escrever com a unba na sua alma, no seu sexo, no seu coração?

E se escreveu laranja no coração, a alma ficará saborosa?

E se escreveu laranja no sexo, o desejo aumentará? 
Onde está a vida do homem que escreve, a vida da laranja, a vida do/

poema- a vida, sem mais nada- estará aqui?

Fora das muralhas da cidade?

(Poeira de Lume. In: O Medo. pp 649/650)

O poema pergunta exatamente sobre aquele homem da cabeça de vidro recolhido fora dos muros do mundo. É o poeta, o que somente em liberdade pode inventar na integridade a vida que no poema se condensa na laranja que após o gesto criador, o poeta contempla, resultado do movimento da sua escrita ferindo alma, sexo e coração. O poeta inventa a laranja, o sabor, o desejo.A vida enfim. E se ele assim o faz e assim se define, por que, pergunto, aquela década sem paixão? Jamais atreveria a responder, mas simplesmente a indicar que década sem paixão, é simplesmente a década, de onde se ausentaram prazeres, desejos, dores, por que não? Aquela mesma ausência que Pasolini se recusara a nomear mas que se manifesta com eloqüência brutal em seu filme Saló, significativamente inventado para corporificar o contexto da brutalidade moral do fascismo.

Neste primeiros anos de um novo século em que o ciclo dessa grande dissolução ainda não parece ter-se fechado, em que apesar das criações da biociência, nenhum antídoto se inventou contra os estigmas moralistas e contra a complacência com que a pósmodernidade revertou as grandes conquistas morais, sociais e políticas das décadas heróicas do séculoXX, talvez resista das vidas desses três grandes artistas a grande mensagem que se acha simbolizada na imagem dos "dedos incandecentes" do poeta, os que inventam por sob a "pele negra do desgosto" ou por sob os escombros do grande consumismo, o vigor e a pureza de um mundo sem moeda de troca. Ou sem moeda. Como o diria $\mathrm{Al}$ Berto num de seus momentos finais:

a noite ardendo

desperta o coração.

depois

talvez se ouca o canto quase limpido

do mundo-cinzas onde mergulho

para abrir o tempo e visitar tuas mãos

que a lucidez, do amor escureceu.

(Poeira de Lume in O Medo. p. 658)

(Entregue para publicação em Março/2007, Aprovado em Abril/2007) 


\section{NOTAS}

1 A Vida Clara. São Paulo. Companhia das Letras. 1993

2 Uma visão mais detalhada sobre a atividade intelectual do filósofo foi escrita pelo seu colega e amigo, Carlos Franchi,e publicada na Folha de S.Paulo por ocasião de seu falecimento

3 Desse repouso nasceria sua tese de mestrado, orientada por G.Gaston Granger e publicada pela Editora Ática sob o nome de Sobre a Noção de Dêixis. São Paulo. Ática. 198...

4 1964. Arco Film. Produção de Alfredo Bini. Locações em Palermo. Calábria. Nápoles, Vale do Pó e vários pequenas localidades da Itália. Não tenho registro de que a película tenha sido projetada no Brasil. Sobre o cineasta apoio-me nos escritos e conferências do próprio Michel Lahud, bem como no livro de Maria Betânia Amoroso A Paixão do Real, em que a pesquisadora analisa sobretudo o pensamento crítico de Pasolini. Sobre sua biografia tenho como referência Pasolini- Réquiem de Barth David Schwartz. First Vintage Books Edition. Nova York. 1995

5 Publicado como anexo em A Vida Clara, 1993 , e na Folha de São Paulo. Debates e Tendências. (2/11/1985) sob o título "O poema de Pasolini para o Brasil"

6 Dentre os inúmeros depoimentos sobre o tema, destaco os da infectologista de São Paulo, Dra Valéria Petri, uma das pioneiras não só da "descoberta" da doença no Brasil, mas, sem dúvida alguma, uma das mais sensíveis pesquisadoras sobre o tema em nosso país.

7 A referência aqui vem a ser o texto de Pasolini, "L 'articolo delle lucciole", Scritti Corsari, Milão, Garzanti, 1975. cuja tradução brasileira saiu em Pasolini, Os Jovens Infeližes, S. Paulo. Ed. Brasiliense, 1990.

8 Remeto ao primeiro volume da edição do Livro do Desassossego feita por Teresa Sobral Cunha. Lisboa. Relógio d 'Água. 1997

9 Al Berto, O Medo. $3^{\text {a }}$. Edição.Lisboa. Assírio e Alvim. 2005

10 Não vou aqui repassar a vasta bibliografia sobre o assunto. Para o interesse deste ensaio, remeto aos textos de Gianni Vattimo, O fim da modernidade. Trad. bras . São Paulo . Martins Fontes.2002 e sobretudo Depois da Cristandade. Rio. Record. 2002.

11 Curioso é notar um processo de remissão que guarda um certo parelelismo idealista nesses pensadores; Vattimo evoca em sua obra aos românticos como Schegel enquanto Pasolini, como o assinalo no ensaio, remete a um substrato arcaico e a uma espécie de vivência pré-industrial nas sociedades contemporâneas. 